\title{
Introduction: beyond the witch trials
}

\author{
Owen Davies and Willem de Blécourt
}

The so-called Enlightenment of the eighteenth century has often been portrayed as a period in which much of Europe cast off the belief in witchcraft and magic under the influence of new philosophies, and advances in science and medicine. This received wisdom has often led to the academic dismissal of the continued relevance of the belief in witchcraft and magic, not only for the poor and illiterate in society but also for the educated. This book seeks to counter this scholarly tendency, by looking at aspects of the continuation of witchcraft and magic in Europe from the last of the secular and ecclesiastical trials during the late seventeenth and early eighteenth centuries, through to the nineteenth century. It will examine the experience of and attitudes towards witchcraft from both above and below, in an age when the beliefs and 'worldview' of the 'elite' and the 'people' are often thought to have irrevocably pulled away from one another. It is too crude and misleading to portray the Enlightenment as a period of intellectual and social leaps. It should rather be seen as a period of subtler renegotiation between cultures, and a period when the relationship between private and public beliefs became more problematic and discrete, and therefore more difficult for the historian to detect. The study of witchcraft and magic provides us with an important means of exploring these broad changing patterns of social relations and mentalities, just as it has done much to help our understanding of social relations in sixteenth- and seventeenth-century society.

Yet the 'beyond' in the title of this book refers not only to the chronological emphasis of its contents, but is also indicative of the different methodological approaches that can be applied to the last of the trials, and the variety of sources that can be used to illuminate our understanding of the continued relevance of witchcraft once it was decriminalised. The contributors come from different academic disciplines, and by borrowing from literary theory, archaeology and folklore they move beyond the usual historical perspectives and sources. The emphasis is not so much on witchcraft trials but on the aftermath of trials, not so much on the persecution of witches but 
on the prosecution of cunning-folk, not so much on supposed female relations with the Devil but on male satanic pacts, less on the declining belief in witchcraft and magic and more on the continuance of related beliefs across the social spectrum.

At present, no single academic discipline dominates the study of witchcraft and magic in the modern period. One might expect historians to have made the subject their own, but for several reasons they have been hesitant to give the late- and post-trial years the same attention as the period of the rise and main phase of witch prosecutions. In particular, historians' tendency to restrict their research interests within arbitrary, academically prescribed periods rather than within subject areas has meant that the interests of historians of witchcraft rarely continue beyond the early modern period. The category 'early modern' is part of the problem in a European context. It attributes a wide range of similar political, social, economic and cultural developments to the same chronological parameters, regardless of the complexities of cultural relations across social levels and geographical regions. The decriminalisation of witchcraft is one such broad development that defines the end of the early modern. Yet the majority of people across Europe undoubtedly felt exactly the same about witches, and much else besides, whether they lived in the early seventeenth century or the early nineteenth century. Academic periodisation certainly has its uses, and historians cannot be expected to develop an equal breadth and depth of knowledge about society in general over the last half millennium. But if we are fully to understand human experience and specific aspects of it such as witchcraft, we must be prepared to move beyond the received boundaries with far more confidence.

That said, the subject has attracted some interest in the last few decades, and increasingly so in the last few years. Historians of witchcraft in early modern western Europe, such as Jim Sharpe, Malcolm Gaskill, Wolfgang Behringer, Robert Muchembled and Eva Labouvie, have pushed forward the boundaries of their work to consider witchcraft in the decades of intermittent prosecution before decriminalisation, the debates that followed in the decade or so after, and to recognise the continued enactment of popular justice against suspected witches. ${ }^{1}$ Several collections of essays with an early modern focus have conscientiously included contributions concerning the continued belief in witchcraft and magic. ${ }^{2}$ Ronald Hutton, an eminent historian of early modern England has, in recent publications concerning paganism, contemporary witchcraft and shamanism, shown how skilled historians can apply their craft and range of experience to illuminate subjects in periods beyond their initial specialisation. ${ }^{3}$ The editors of this volume also work across the traditional divide between early modern and modern eras, and in numerous publications have accorded as much attention to the story of witchcraft and magic in the centuries beyond the usual focus on the sixteenth and seventeenth centuries. ${ }^{4}$ De Blécourt's study of the Dutch province of Drenthe is 
the only study of its kind, which meticulously uncovers and analyses the historical data on witchcraft over a 500-year period. ${ }^{5}$ The methodologies and interests of academics like de Blécourt represent a flexible continental historiographical tradition that has less respect for orthodox chronological and disciplinary boundaries. By way of further example, consider Le Roy Ladurie's imaginative detective work into the origins of the witch poem by the mid-nineteenth-century hairdresser-poet Jacques Jasmin, and the work of Éva Pócs in Hungary who has drawn upon early modern archives and twentiethcentury folklore to piece together patterns of belief. ${ }^{6}$

Beyond the witch trials also appears in the wake of the publication of volume five in the Athlone 'History of Witchcraft and Magic in Europe' series, under the general editorship of Bengt Ankarloo and Stuart Clark. ${ }^{7}$ The volume consists of three important and lengthy essays by Brian Levack, Marijke Gijswijt-Hofstra and the late Roy Porter, which respectively deal with the decline of witch prosecutions, the continuance of popular witchcraft beliefs in the eighteenth and nineteenth centuries, and the place of witchcraft in intellectual thought over the same period. An appreciation of these essays has in part shaped the content of this volume. The broad surveys by Porter and Hofstra, while providing an impressive synthesis of work to date also highlight just how little work has been done, and the gaping holes that exist in the coverage of witchcraft beyond the late seventeenth century. The essays in Beyond the trials begin the task of filling in those lacunae geographically and contextually for an English readership.

Compared to the huge and ever increasing historiography concerning the main period of the witch trials, then, the history of witchcraft and magic in the period academia refers to as either the Enlightenment period, or the less value-laden 'long eighteenth century', is in its infancy. Yet the freshness of the subject also presents new opportunities to embrace interdisciplinary and longue durée approaches in the history of witchcraft and magic. Several of the contributors in this volume are scholars who are only just beginning to publish the results of their research, while others are well-established historians who are pushing their own boundaries forward. Bringing together the mix of experience proves rewarding, providing a cross-fertilisation of diverse work from different disciplines at an early stage in the field, so that future work can be informed by a variety of methodologies and sources. It is surely significant that despite the diversity of the contributions in this respect, three broad themes emerge in the chronological and conceptual context of the 'Enlightenment' period.

The first concerns the shifting intellectual interpretation of folk magic from being a very real and implicitly satanic offence to being a merely fraudulent and morally reprehensible crime. Inextricably tied up with this process was the use and changing definition of 'superstition' - a subject that is ripe for further research. ${ }^{8}$ The word has long been used in a derogatory 
sense to describe what were perceived to be unfounded, credulous or heretical beliefs. Ancient Roman and Greek authors applied it to 'uncivilised' people outside the Classical world. The early Church used it in its campaign against the pagan religions which it ultimately vanquished. In Reformation Europe the word became a confessional swear word used by Protestants to characterise Catholic devotional practices, meanwhile the Catholic Church also used it against its own laity who dared assume clerical powers or who resorted to unsanctioned forms of piety. This confessional use of 'superstition' was still prevalent in the Enlightenment period, particularly in Protestant countries, but as several of the articles in this volume show, the term also underwent a process of secularisation. It was appropriated as an Enlightenment tool, and added to the arsenal of words used to enforce a self-conscious intellectual and cultural break with the past. It was a term of abuse that secular Catholic intellectuals threw at the theologians who clung fervently to the notion of witchcraft. ${ }^{9}$ It was likewise used by intellectuals in Protestant countries. It was also a label applied to the cultures of the 'lower orders' as a means of clearly demarcating the world of the 'ignorant' from the educated, the 'irrational' from the rational. In this sense 'superstition' became the antithesis of modernity.

Marie Lennersand's innovative account of the aftermath of the major witch trials in Dalarna, Sweden, demonstrates how the authorities began this awkward process of divorcing themselves from popular concerns and beliefs regarding witchcraft. This shift led, it would seem, to some considerable consternation amongst the witch-believing public as to what was and was not regarded as criminal. Yet while the criminal basis of witchcraft was increasingly undermined by legal circumspection regarding the nature of evidence, and broader intellectual scepticism concerning the reality of witchcraft, beneficial magic remained a crime even though it was rationalised according to intellectual developments. This is particularly clear in the article by Raisa Toivo. She shows how the secular and religious authorities in Finland, at the time under Swedish rule, proactively turned the focus of prosecutions under general laws for witchcraft and 'popular' magic firmly in the direction of the latter. While popular concern remained focused on harmful witchcraft, the pattern of prosecutions during the late seventeenth and early eighteenth centuries show a determined shift towards authoritarian rather than popular preoccupations. Increasingly it was the authorities rather than the general population who brought prosecutions, albeit they were still based on information reported by 'lay' folk. Linda Oja's survey of educated Swedish attitudes further illuminates the way in which the concept of magic was secularised, and the label 'superstition' was redefined to reinforce social separation. Yet the 'problem' of magic was not only seen in terms of false religion and the attribution of credulity, but also as a matter of social disharmony. De Blécourt's detailed account of the activities of the 
cunning-man 'Popish Derk' indicates that, by the late eighteenth century, Dutch authorities were as much concerned with the threat to 'ties of good harmony between neighbours' caused by witch doctors as with questions of medical impropriety and immorality. Likewise in early eighteenth-century Spain the attack on exorcists by the Benedictine monk Benito Feijoo was primarily concerned with their threat to social rather than theological order.

It is also clear with regard to witchcraft and magic that the balance between secular and religious criminal jurisdiction was highly variable across Europe. While Oja and de Blécourt suggest that in Sweden and the Netherlands, as in England, the ecclesiastical courts had all but given up on dealing with popular magic by the early eighteenth century, Ferraiuolo's contribution highlights the significant role the Italian Inquisition continued to play in policing 'superstition' during the period. But we should not jump to the conclusion that the chronological and geographical pattern of ecclesiastical judicial involvement can be conveniently divided along strict confessional lines. True, the Inquisitions continued their campaign against 'superstition' on a far more systematic basis. Yet, as Maxwell-Stuart clearly shows, the church courts or kirk sessions of the Calvinist Church of Scotland continued to be active in the prosecution of magic during the first half of the eighteenth century. Furthermore, the decline of ecclesiastical judicial involvement was not necessarily reflective of the level of clerical activity on a personal level. In Toivo's account of the various trials of Agata Pekantytär we find that the parish minister was instrumental in bringing charges against her for practising magic, and the late prosecution against supposed witches from Dalarna in 1757 , mentioned by Oja, proceeded due to the wishes of the regional head of the Church. In the Bristol Lamb Inn possession case, so meticulously analysed by Jonathan Barry, ecclesiastical involvement was considerable, and the intellectual discourse regarding it was framed by the tensions both within Anglicanism and with Nonconformity. In this sense the views and activities of the Spaniard Father Benito Feijoo, as described by Maria Tausiet, should not be seen as distinctly Catholic but rather as part of a wider intellectual debate about supernatural interventionism in eighteenth-century Europe.

This leads us on to the second theme to emerge from the contributions to this volume, which concerns the considerable continued intellectual interest regarding diabolic intervention in human affairs. Educated society may have become increasingly disengaged from the concept and problem of witchcraft during the early eighteenth century, but the question of possession and satanic pacts remained a major topic of earnest debate and authoritarian perplexity. ${ }^{10}$ Feijoo's discourse on possession may seem at first to be a defining Enlightenment attack. Yet, as Tausiet shows, Feijoo's unmasking of the fraud and delusion involved did not lead him to reject completely that some people, albeit a very small number, were truly possessed. Some of the respected urban citizens who investigated the possessed girls at the Lamb 
Inn in 1761-62 were comforted to find confirmation of their belief in satanic intervention. At the same time they were also anxious to distance themselves from popular interpretations of the symptoms in terms of witchcraft. SoiliMaria Olli's analysis of the trials for Devil's pact brought before the Swedish High Court demonstrates how authoritarian concern regarding male satanic relations outlived the more specific diabolic crime of witchcraft. One obvious reason for this was that men actually drew up agreements with the Devil, and so there was concrete evidence on which to base prosecutions. As the eighteenth century progressed, the High Court increasingly concluded that those who sought to make pacts were merely ignorant, stupid or ill, but they nevertheless continued to investigate rigorously such cases.

The third theme concerns the centrality of the written and printed word to the experience of witchcraft and magic. On one level, as Augusto Ferraiuolo demonstrates, the possession of literacy profoundly shaped the context and content of the criminal records used by historians. As his textual analysis of denunciations of popular magic brought before the Italian Inquisition shows, the act of transcribing the accounts of the illiterate into a written narrative reveals much about the relationship between individual and institution with regard to mentalities and social control. At another level, the eighteenth century saw an increasing popular access to and engagement with printed material. While the extent of the growth of literacy during the Enlightenment is a matter of considerable debate, there is no doubt that there was a publishing boom, and that it was partly inspired by a popular thirst for literary knowledge. The rise of such printed formats as periodicals and newspapers have been seen as instrumental in the spread of enlightened knowledge across society. Yet as the work by Sabine Doering-Manteuffel and Stephan Bachter shows, the printing presses were equally instrumental in promoting and disseminating counter-Enlightenment modes of thought. They outline the rise of a 'magic media market', characterised by the popularisation of once intellectual occult subject matter, and the publication in German of once scarce manuscript sources. These developments were to have an impact far beyond European shores.

Considering that the eighteenth century saw a significant widening of access to written sources of knowledge, it seems rather ironic that historians should be put off studying witchcraft and magic in the post witch trial period by a perceived paucity of material. As the contributions to this book show, in the absence of witch-prosecution records there are a range of alternative sources to be consulted. Significant numbers of what have been termed 'witch trials in reverse', where those assaulted for being suspected witches prosecuted their assailants, await discovery in court records. ${ }^{11}$ As de Blécourt shows in his contribution slander trials also provide further valuable insights into witchcraft accusations. Across Europe, long after the laws against witchcraft were repealed, the crime of pretended witchcraft and magic 
continued on the statute books. It was under these laws and other statutes against illegal medical practice and vagrancy that cunning-folk found themselves in court. These trial records provide further insights regarding the dynamics of witch accusations as well as the nature of magical healing and divination. There are a variety of other sources waiting to be tapped. For example, that icon of the Enlightenment, the newspaper, has yet to be properly exploited for the information it contains on the subject. As limited work on English newspapers has shown, and as Doering- Manteuffel's and Bachter's contributions indicate, it is not only newspaper court reports that the historian of witchcraft and magic needs to examine but also the public notices and advertising columns. ${ }^{12}$ Furthermore, as Brian Hoggard's article demonstrates, historians should also raise their gaze beyond the manuscript or printed page. A consideration of archaeological as well as literary material can help fill some of the gaps in our knowledge. Literary sources offer only a selective history of the past. Archaeological artefacts provide evidence of popular magical practices, such as the widespread entombment of cats and shoes, which have left no trace in the archives. Hoggard's research further confirms that we need to show more interdisciplinary awareness.

Although the history of the main period of the witch trials is far from exhausted, it could be said that we are approaching saturation point in some respects regarding focus and methodology. The essays in this book, while applying established approaches to a later period of study, also provide signposts to new directions for further research by shifting the interpretive parameters. In this respect it is hoped that Beyond the witch trials will help push the boundaries of witchcraft research into new times and territories.

\section{Notes}

1 James Sharpe, Instruments of Darkness: Witchcraft in England 1550-1750 (London, 1996); Malcolm Gaskill, Crime and Mentalities in Early Modern England (Cambridge, 2000); Gaskill, Hellish Nell: Last of Britain's Witches (London, 2001); Wolfgang Behringer, Witchcraft Persecutions in Bavaria: Popular Magic, Religious Zealotry and Reason of State in Early Modern Europe (Cambridge, 1997; German edition 1987); Robert Muchembled, La sorcière au village, XVe-XVIIIe siècles (Paris, 1979); Eva Labouvie, Verbotene Künste. Volksmagie und ländlicher Abergalube in den Dorfgemeinschafen des Saaraumes (16-19 Jahrhundert) (St Ingbert, 1992). For North America see John Butler, 'Magic, Astrology, and the Early American Religious Heritage, 1600-1760', American Historical Review 84 (1979) 317-46; John Putnam Demos, Entertaining Satan: Witchcraft and the Culture of Early New England (Oxford, 1982).

2 Marijke Gijsiwjt and Willem Frijhoff (eds), Nederland betoverd. Toverij en hekserij van de veertiende tot in de twintigste eeuw (Amsterdam, 1987) [published in a reduced English edition as Witchcraft in the Netherlands from the Fourteenth to the Twentieth Century (Rotterdam, 1991)]; Robert Muchembled (ed.), Magie et sorcellerie en Europe du Moyen Age à nos jours (Paris, 1994); Jonathan Barry, Marianne Hester and Gareth Roberts (eds), Witchcraft in Early Modern Europe (Cambridge, 1996); Julian Goodare (ed.), The Scottish Witch-Hunt in Context (Manchester, 2002). 
3 Ronald Hutton, The Triumph of the Moon: A History of Modern Pagan Witchcraft (Oxford, 1999); Hutton, Shamans: Siberian Spirituality and the Western Imagination (London, 2002).

4. See, for example, Owen Davies, Cunning-Folk: Popular Magic in English History (London, 2003); Willem de Blécourt, 'On the Continuation of Witchcraft', in Barry, Hester and Roberts (eds), Witchcraft, pp. 335-52.

5 Willem de Blécourt, Termen van toverij. De veranderende betekenis van toverij in Noordoost-Nederland tussen de 16de en 20ste eeuw (Nijmegen, 1990).

6 Emmanuel Le Roy Ladurie, Jasmin's Witch: An Investigation into Witchcraft and Magic in South-West France During the Seventeenth Century, trans. Brian Pearce (London, [1983] 1990); Éva Pócs, Between the Living and the Dead: A Perspective on Witches and Seers in the Early Modern Age, trans. Szilvia Rédey and Michael Webb (Budapest, 1999).

7 Marijke Gijswijt-Hofstra, Brian P. Levack and Roy Porter, Witchcraft and Magic in Europe: The Eighteenth and Nineteenth Centuries (London, 1999).

8 For a useful overview of the interpretive problems see the introduction in Helen Parish and William G. Naphy (eds), Religion and Superstition in Reformation Europe (Manchester, 2002).

9 An excellent example of this can be found in Wolfgang Behringer's account of the 'Bavarian witchcraft war' of 1766-70: Behringer, Witchcraft Persecutions, pp. 359-87.

10 For an overview and references see Roy Porter, 'Witchcraft and Magic in Enlightenment, Romantic and Liberal Thought', in Gijswijt-Hofstra, Levack and Porter, Witchcraft and Magic, pp. 191-283.

11 Gustav Henningsen, 'Witch Persecution after the Era of the Witch Trials', ARV. Scandinavian Tearbook of Folklore 44 (1988) 103-53; Henningsen, 'Witchcraft in Denmark', Folklore 93 (1982) 131-7.

12 Owen Davies, Newspapers and the Popular Belief in Witchcraft and Magic in the Modern Period', Journal of British Studies 37 (1998) 139-66. 